\title{
Rainfall-runoff model using the SCS-CN method and geographic information systems: a case study of Gomal River watershed
}

\author{
M. Kh. Askar \\ Salahaddin University, Kurdistan Region, Iraq
}

\begin{abstract}
s
This research aims to determine the runoff depth using the Soil Conservation Service Curve Number (SCS-CN) method with Geographic Information Technique (GIS). A rainfall-runoff model is a mathematical model describing the rainfall-runoff relations of a catchment area, drainage basin or watershed. Remote sensing technology can augment the conventional methods to a great extent in rainfall-runoff studies. The role of remote sensing in runoff calculation is generally to provide a source of input data or as an aid for estimating equation coefficients and model parameters. The study was carried out in the Gomal River watershed about $540 \mathrm{~km}^{2}$ catchment areas, Latitude: $36.5155556^{\circ}$, Longitude: $43.5144444^{\circ}$. The area within the boundary of the Kurdistan region starts from north of Shahia to south west of Dohuk City. A SCS-CN method was applied for estimating the runoff depth in the semi-arid Gomal watershed. Hydrologic stream flow, soil group, slopes and land use maps were generated in a GIS environment. The curve number method was used to estimate the runoff depth for selected storm events in the watershed. Effect of slope on $\mathrm{CN}$ values and runoff depth was determined by using the WMS 7.1 program. The max rainfall depth with different return period was calculated and the mean annual rainfall depth for the year 1947 to 2005 of Mosul metrological station was used to calculate the runoff depth of the catchment area. The results of the WMS 7.1 program showed that the $\mathrm{CN}$ curve number for the area is about 80 . The average annual runoff depth is equal to $311.14 \mathrm{~mm}$
\end{abstract}

Keywords: remote sensing, geographical information systems, watershed, SCSCN rainfall-runoff modelling, WMS 7.1 program. 


\section{Introduction}

A rainfall-runoff model is a mathematical model describing the rainfall-runoff relations of a catchment area, drainage basin or watershed. A rainfall runoff model can be really helpful in the case of calculating discharge from a basin.

Reliable prediction of quantity and rate of runoff from land surface into streams and rivers is difficult and time consuming to obtain for un-gauged watersheds. However, this information is needed in dealing with many watershed development and management problems. Conventional models for prediction of river discharge require considerable hydrological and meteorological data. Collection of these data is expensive, time consuming and a difficult process.

There are several approaches to estimate un-gauged basin runoff. Examples are the University of British Columbia Watershed Model (UBCWM), Artificial Neural Network (ANN), SCS Curve Number model, and Geo-morphological Instantaneous Unit Hydrograph (GIUH). Among these methods, the SCS Curve Number method is widely used because of its flexibility and simplicity. The method combines the watershed parameters and climatic factors in one entity called the Curve Number (CN). Many researchers (Pandey and Sahu [1]; Nayak and Jaiswal [2]; Zhan and Huang [3]; Gandini and Usunoff [4]) have utilized the Geographic Information System (GIS) technique to estimate runoff Curve Number value throughout the world. In India, Pandy and Sahu pointed out that the land use/land cover is an important parameter input of the SCS-CN model. Nayak and Jaiswal found that there was a good correlation between the measured and estimated runoff depth using GIS and CN.

They concluded that GIS is an efficient tool for the preparation of most of the input data required by the SCS curve number model. Akhondi [5] pointed out that correlation between observed and estimated discharge using $\mathrm{CN}$ method is decreased by increasing watershed area. While having runoff data is essential in all watershed development and management plans, very little work has been previously done in the watersheds of Iran in estimating runoff from rainfall in ungauged watersheds.

For drainage basins where no runoff has been measured, the curve number method, SCS-CN can be used to estimate the depth of direct runoff from the rainfall depth, given an index describing runoff response characteristics.

The Curve Number Method was originally developed by the Soil Conservation Service (Soil Conservation Service 1964; 1972) for conditions prevailing in the United States. Since then, it has been adapted to conditions in other parts of the world. The method is summarized by using curve numbers to represent a single parameter relation between rainfall depth and runoff depth. The single parameter relation is $\mathrm{S}$; the transform of $\mathrm{S}$ is $\mathrm{CN}$ (Clapper [6]).

\section{Study area description}

The catchment area of Gomel River is within Kurdistan region. The area is start from north of Shahia to south west of Dohuk City, Latitude: $36.5155556^{\circ}$, 


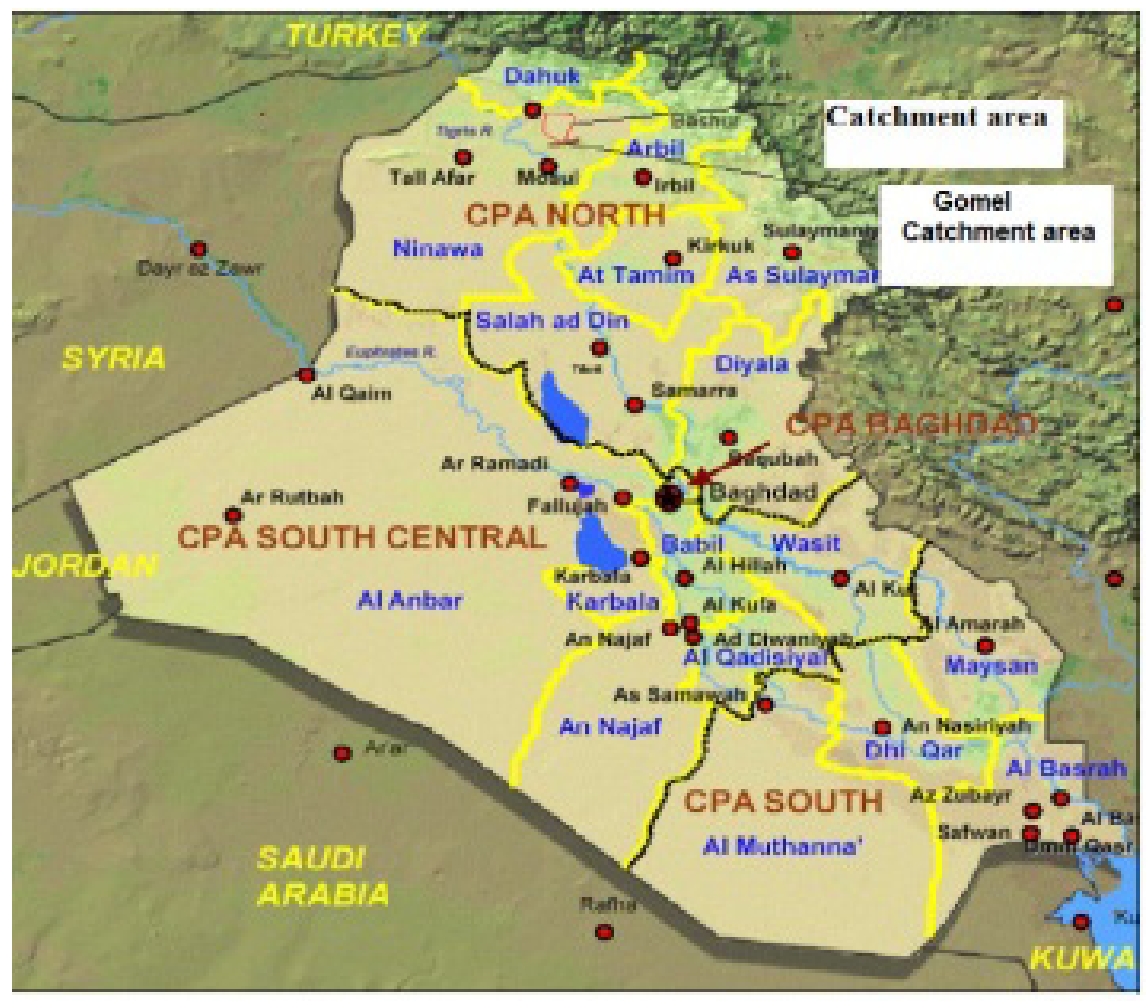

Figure 1: Location of the catchment area.

Longitude: $43.5144444^{\circ}$. The Gomal River is a tributary of Khazer River (Figure 1). The Gomel catchment area is about $540 \mathrm{~km}^{2}$.

The area consists of series of high, wide and comparatively long extended mountains separated by long synclines. There is no any barrier within the drainage streams of the watershed. The main mountains falls in the high folded zone are: Kamaka, Chiya Pang, and Kiri-Rabatki. The maximum and minimum heights within the GIS topographic map area are 2170 and $350 \mathrm{~m}$ (a.s.l), respectively (Figure 2(a) and (b)). The highest point is located in Chiya Pang Mountain in the eastern part of the area whereas the lowest point is near the river to the north of Shahia village. The summary of characteristics of the area is as follows:

The area is about $524.48 \mathrm{~km}^{2}$, watershed slope is $0.2216 \mathrm{~m} / \mathrm{m}$, average over land flow is $0.74 \mathrm{~km}$, north aspect is $0.42 \%$, south aspect $0.58 \%$, watershed length is $36.32 \mathrm{~km}$, perimeter $152.3 \mathrm{~km}$, average elevation $934.2 \mathrm{~m}$, max. flow distance is $52 \mathrm{~km}$, max. flow slope is $0.019 \mathrm{~m} / \mathrm{m}$, max. stream length is $49.96 \mathrm{~km}$ and max. stream slope is $0.0124 \mathrm{~m} / \mathrm{m}$. 


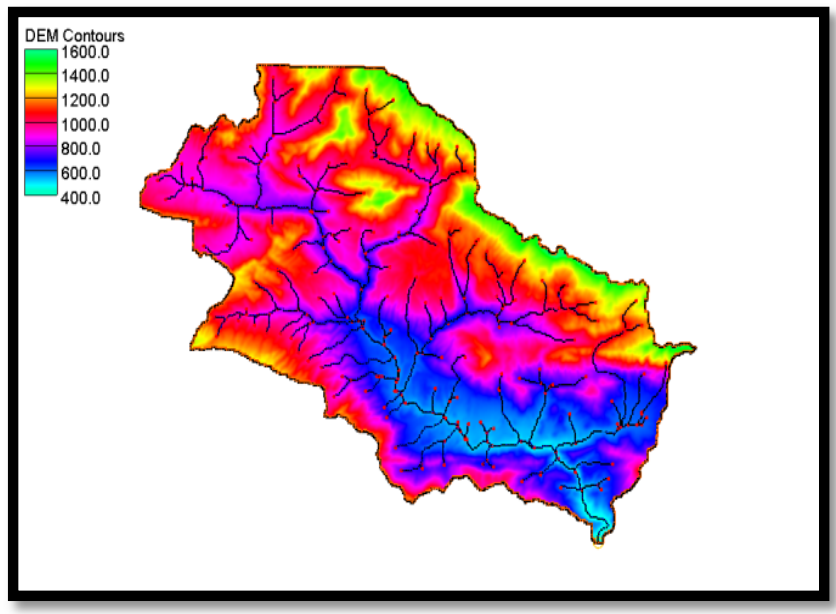

(a) Topographical catchment area

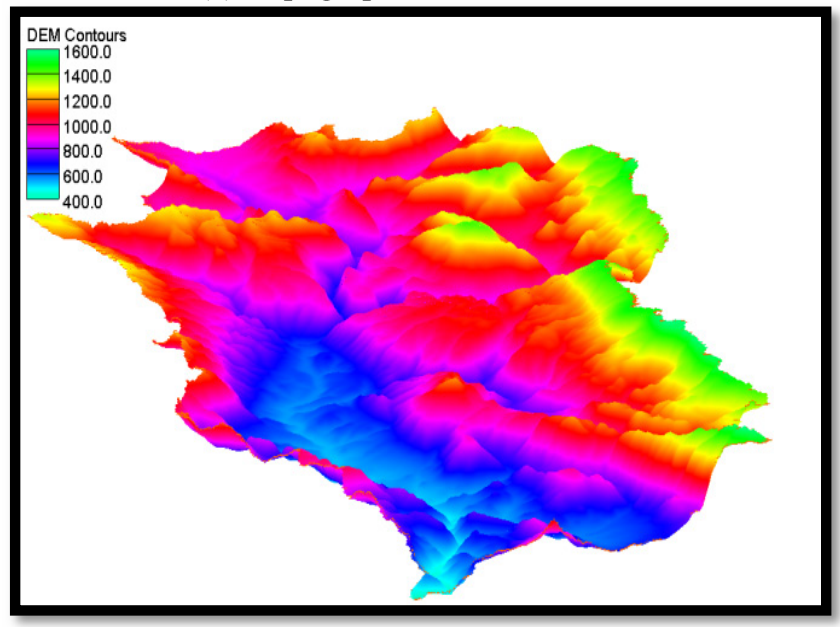

(b) Three dimensional catchment area

Figure 2: (a) Topographical catchment area, (b) three dimensional catchment area.

\section{Hydrogeology}

Gomel sub basin is belongs to Great Zab River basin, considered as the largest one within the main basin, according to satellite image as shown in Figure 3, the basin is drained by two main synclinal valleys which flow towards east and between Shkira, Kiri-Habakara, Duda Rash and Ain-Sifni mountains, from north to south respectively they have the same direction of the main strike of the bed which is E-W. The surface runoff is high in the higher parts (northern synclines) due to lack of vegetation and high gradient, but because the lower parts of the 
sub basin has nearly horizontal gradient with sediments of good permeability, so it is believed that the majority of the water is infiltrated and flow as ground water. The main sources of the water are perennial streams (which flow mainly in the synclinal valleys besides the rainfall and spring, snow cover some of the high mountains which supply good quantity of water after melting. The main annual precipitation also differs in these mentioned parts.
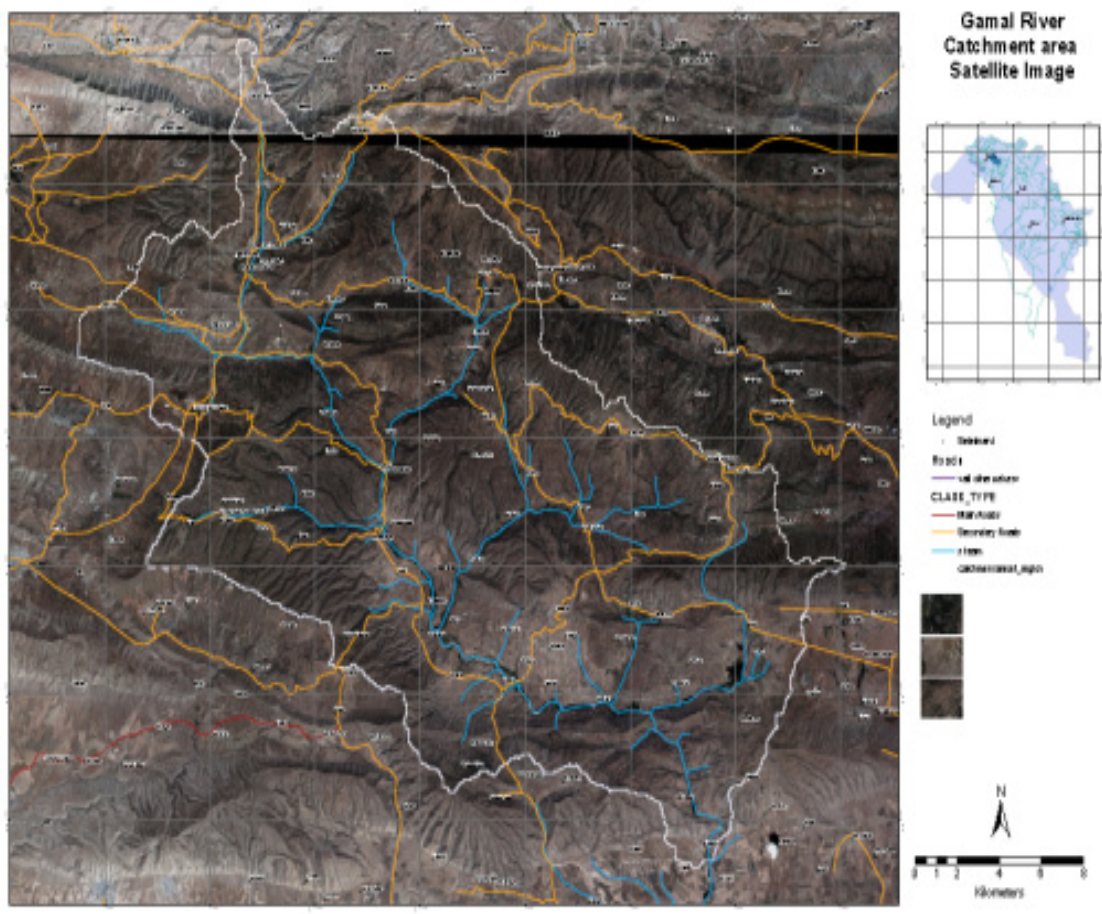

Figure 3: Gomal River catchment area satellite image.

The areas of limestone outcrops specially those of Pilaspi, Aqra-Bekhma formations have good to high infiltration capacity due to high porosity which is either primary and or secondary due to dolomitization, fracturing and solution cavities, even that due to structured aspects of the area. The discharge of the valley is about $1.5 \mathrm{~m}^{3} / \mathrm{s}$ in September and October while the discharge may reach $300 \mathrm{~m}^{3} / \mathrm{s}$ during heavy rainfall storm and snow melting at March and April.

\section{Structural geology}

The area lies in the northern part of the northern thrust zone, whilst the Shaikan and Al-Qush Anticlines represent the separating line of High Folded Zone from Foot Hill Zone (Dunnington [7]). The area occupies Amadiya block and partly of Shaqlawa block which belongs to Amadiya - Shaqlawa Sub Zone (Buday [8]), 
these structure zones belong to the Unstable Shelf of Nubio - Arabian Platform, Figure 4 . The area is generally comprised of several anticline and synclines and the anticlines which have nearly parallel axis represent high mountain range i.e. Aqra and Shaikan anticlines.
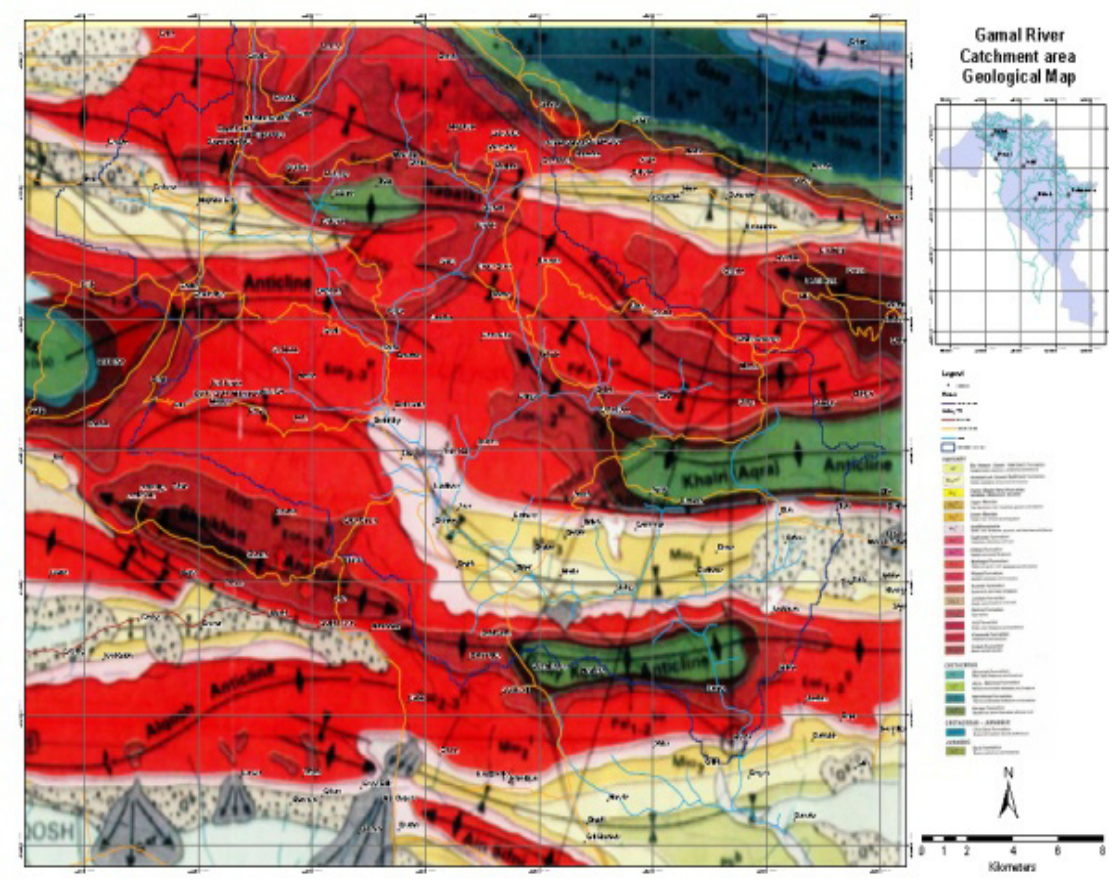

Figure 4: Gomal River catchment area geological map.

\section{Methodology}

The SCS curve number method is a simple, widely used and efficient method for determining the approximant amount of runoff from a rainfall even in a particular area. Although the method is designed for a single storm event, it can be scaled to find average annual runoff values. The stat requirements for this method are very low, rainfall amount and curve number. The curve number is based on the area's hydrologic soil group, land use, treatment and hydrologic condition.

Normally the SCS model computes direct runoff with the help of the following relationship (Handbook of Hydrology, 1972)

where,

$$
\begin{gathered}
\mathrm{S}=(24500 / \mathrm{CN})-254 \\
\mathrm{Q}=((\mathrm{P}-0.3 \mathrm{~S}) 2) /(\mathrm{P}+0.7 \mathrm{~S}) \\
\mathrm{CN}=(\Sigma(\mathrm{NCi} \mathrm{X} \mathrm{Ai})) / \mathrm{A}
\end{gathered}
$$

$\mathrm{CN}=$ weighted curve number. 
$\mathrm{CNi}=$ curve number from 1 to any no. $\mathrm{N}$.

$\mathrm{Ai}=$ area with curve number $\mathrm{CNi}$

$\mathrm{A}=$ the total area of the watershed.

where, $\mathrm{CN}$ is the runoff curve number of hydrologic soil cover complex, which is a function of soil type, land cover and antecedent moisture condition (AMC); $\mathrm{Q}$, actual direct runoff, $\mathrm{mm}$; $\mathrm{P}$, total storm rainfall, $\mathrm{mm}$; and $\mathrm{S}$, the potential maximum retention of water by the soil, $\mathrm{mm}$.

The runoff curve number method is procedure for hydrological abstraction developed by the USDA Soil conservation service (Ponce [9]). The runoff curve number method was developed based on 24-hr rainfall- runoff data.

where

$$
Q=\frac{R\left(C N\left(\frac{P}{R}+2\right)-200\right)^{2}}{C N\left(C N\left(\frac{P}{R}-8\right)+800\right)}
$$

$\mathrm{R}=2.54, \mathrm{P}=$ rainfall $(\mathrm{mm}), \mathrm{Q}$ runoff $(\mathrm{cm})$,

\section{Geographic information systems, GIS}

\subsection{Soil type}

Soils are classified into four classes A, B, C and D based on the ground slope, infiltration, and other characteristics. The important soil characteristics that influence the hydrological classification of soils are effective depth of soil, average clay content, infiltration characteristics and the permeability as follow: group A: low runoff potential, group B: moderately low runoff potential, group C:moderate high runoff potential and group D: high runoff potential.

\subsection{Antecedent moisture condition, AMC}

AMC refers to the moisture content present in the soil at the beginning of the rainfall-runoff event under consideration. It is well known that initial abstraction and infiltration and are governed by AMC. The runoff curve number has three levels of antecedent moisture, depending on total rainfall in the 5- day period. For purposes of practical application, three levels of AMC are recognized by SCS as follows: AMC-I: Soils are dry but not to wilting point. Satisfactory cultivation has taken place, AMC-II: Average conditions, AMC-III: Sufficient rainfall has occurred within the immediate past five days. Saturated soil conditions prevail.

\subsection{Land use and treatment}

The effect of the surface condition of a watershed is evaluated by means of land use and treatment classes. Land use is classified into three groups: poor, fair, and good as shown: poor: less than $30 \%$ ground cover, fair: 30 to $70 \%$ ground cover and good: more than $70 \%$ ground cover. 
The variation of curve number under AMC II called CNII for various land conditions. The conversion of CNII to other two AMC conditions can be made through the following correlation equations:

For AMC ICNII/(2.281-0.01281CNII)

For AMC III $I I /(0.427+0.00573 C N I I)$

\section{Results and discussion}

The GIS software was used in the present study. The boundary of the catchment area and all the streams were mapped. The watershed divided into ninety seven sub-basin in order to fulfil the requirement of SCS model. . The max length of stream and the area for every sub-basin were calculated. Also, a contour map was prepared. Table 1 provides the details of these geo-morphological characteristics for the Gomal catchment.

In the present work the Gomal basin, which lies in Iraq/Kurdistan Region has been selected as the area of study. The modelling being simulated by method SCS-CN curve number the results have been compared with observed data.

Table 1: The details of geo-morphological characteristics for the Gomal catchment.

\begin{tabular}{|c|c|c|c|c|c|c|c|c|}
\hline 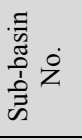 & 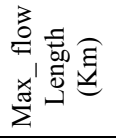 & 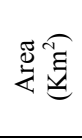 & 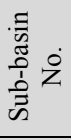 & 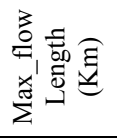 & 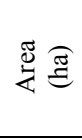 & 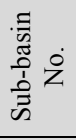 & 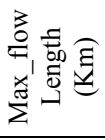 & 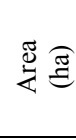 \\
\hline 0 & 5 & 16.99 & 8 & 3 & 4.92 & 16 & 8 & 7.93 \\
\hline 1 & 5 & 20.48 & 9 & 2 & 7.79 & 17 & 6 & 9.12 \\
\hline 2 & 2 & 9.61 & 10 & 5 & 3.20 & 18 & 17 & 0.67 \\
\hline 3 & 13 & 13.47 & 11 & 6 & 7.82 & 19 & 2 & 0.04 \\
\hline 4 & 2 & 4.33 & 12 & 2 & 4.53 & 20 & 6 & 11.93 \\
\hline 5 & 4 & 7.31 & 13 & 3 & 12.11 & 21 & 13 & 1.25 \\
\hline 6 & 4 & 5.20 & 14 & 6 & 0.16 & 17 & 6 & 9.12 \\
\hline 7 & 5 & 5.40 & 15 & 2 & 4.03 & 18 & 17 & 0.67 \\
\hline 19 & 2 & 0.04 & 51 & 12 & 1.31 & 76 & 62 & 3.30 \\
\hline 20 & 6 & 11.93 & 52 & 37 & 0.03 & 71 & 61 & 4.33 \\
\hline 21 & 13 & 1.25 & 53 & 39 & 6.01 & 72 & 5 & 9.65 \\
\hline 22 & 17 & 9.05 & 54 & 39 & 5.40 & 73 & 7 & 0.01 \\
\hline
\end{tabular}


Table 1: $\quad$ Continued.

\begin{tabular}{|c|c|c|c|c|c|c|c|c|}
\hline 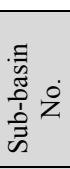 & 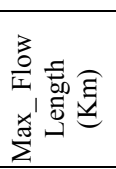 & 蛋泀 & 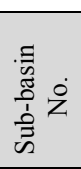 & 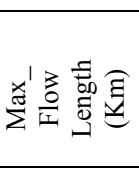 & 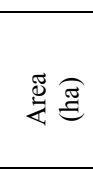 & 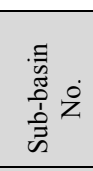 & 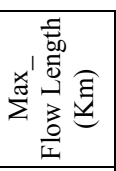 & $\stackrel{\mathscr{J}}{\grave{4}}$ \\
\hline 23 & 18 & 4.97 & 55 & 40 & 2.80 & 74 & 61 & 0.14 \\
\hline 24 & 19 & 0.74 & 56 & 55 & 6.45 & 75 & 7 & 6.32 \\
\hline 25 & 18 & 4.31 & 57 & 40 & 1.86 & 76 & 62 & 3.30 \\
\hline 26 & 30 & 14.72 & 58 & 41 & 2.81 & 77 & 62 & 0.01 \\
\hline 27 & 8 & 3.85 & 59 & 41 & 5.61 & 78 & 63 & 0.32 \\
\hline 28 & 2 & 8.48 & 60 & 57 & 1.75 & 79 & 64 & 20.79 \\
\hline 29 & 19 & 3.87 & 61 & 2 & 9.10 & 80 & 66 & 6.24 \\
\hline 30 & 30 & 6.46 & 62 & 55 & 7.13 & 81 & 74 & 11.76 \\
\hline 31 & 2 & 8.10 & 63 & 2 & 5.83 & 82 & 74 & 5.30 \\
\hline 32 & 2 & 5.04 & 58 & 41 & 2.81 & 83 & 63 & 4.80 \\
\hline 33 & 4 & 4.62 & 59 & 41 & 5.61 & 84 & 75 & 3.96 \\
\hline 34 & 31 & 1.26 & 60 & 57 & 1.75 & 85 & 75 & 0.50 \\
\hline 35 & 2 & 5.72 & 61 & 2 & 9.10 & 86 & 76 & 0.01 \\
\hline 36 & 2 & 5.42 & 62 & 55 & 7.13 & 87 & 76 & 3.20 \\
\hline 37 & 10 & 1.11 & 63 & 2 & 5.83 & 88 & 77 & 0.32 \\
\hline 38 & 7 & 1.69 & 64 & 66 & 1.90 & 89 & 77 & 3.72 \\
\hline 39 & 2 & 8.96 & 65 & 57 & 0.00 & 90 & 79 & 1.91 \\
\hline 40 & 4 & 20.79 & 66 & 64 & 4.85 & 91 & 5 & 5.03 \\
\hline 41 & 4 & 6.05 & 67 & 2 & 0.01 & 92 & 79 & 0.46 \\
\hline 42 & 37 & 11.63 & 68 & 2 & 5.06 & 93 & 5 & 5.42 \\
\hline 43 & 12 & 12.62 & 69 & 58 & 11.85 & 94 & 86 & 1.24 \\
\hline 44 & 10 & 0.01 & 70 & 58 & 7.78 & 95 & 6 & 3.95 \\
\hline 45 & 31 & 4.09 & 70 & 58 & 7.78 & 96 & 6 & 0.95 \\
\hline 46 & 37 & 5.61 & 71 & 61 & 4.33 & 97 & 86 & 4.84 \\
\hline 47 & 7 & 0.64 & 72 & 5 & 9.65 & \multicolumn{3}{|c|}{ Total Area $=540.25$ ha } \\
\hline 48 & 5 & 3.01 & 73 & 7 & 0.01 & & & \\
\hline 49 & 4 & 21.88 & 74 & 61 & 0.14 & & & \\
\hline 50 & 37 & 9.42 & 75 & 7 & 6.32 & & & \\
\hline
\end{tabular}


168 Water and Society II

\subsection{Rainfall}

Mean monthly rainfall of Mosul metrological station from 1947-to 2005 were used for estimating runoff. A summary of the adjustment of Gumbel Distribution Parameters is listed in Table 2.

Table 2: $\quad$ Summary of the adjustment of Gumbel distribution parameters.

\begin{tabular}{|c|c|c|c|c|c|c|c|c|c|c|c|}
\hline 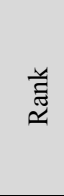 & 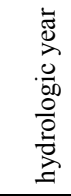 & 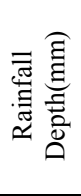 & 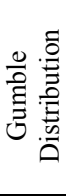 & 䒕 & 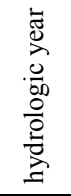 & 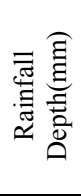 & 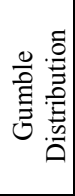 & 䒕 & 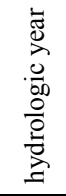 & 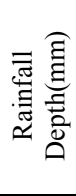 & 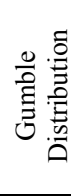 \\
\hline 1.0 & 1993 & 709.2 & 0.02 & 21.0 & 1964 & 403.1 & 0.35 & 41.0 & 1975 & 320.8 & 0.68 \\
\hline 2.0 & 1988 & 676.0 & 0.03 & 22.0 & 2004 & 399.9 & 0.37 & 42.0 & 2003 & 313.6 & 0.70 \\
\hline 3.0 & 1954 & 643.2 & 0.05 & 23.0 & 1982 & 394.5 & 0.38 & 43.0 & 1962 & 309.3 & 0.72 \\
\hline 4.0 & 1969 & 632.9 & 0.07 & 24.0 & 1968 & 392.8 & 0.40 & 44.0 & 1986 & 309.3 & 0.73 \\
\hline 5.0 & 1949 & 556.9 & 0.08 & 25.0 & 1956 & 371.6 & 0.42 & 45.0 & 1951 & 301.6 & 0.75 \\
\hline 6.0 & 1963 & 524.1 & 0.10 & 26.0 & 1998 & 371.3 & 0.43 & 46.0 & 1961 & 300.7 & 0.77 \\
\hline 7.0 & 1980 & 501.0 & 0.12 & 27.0 & 1990 & 365.1 & 0.45 & 47.0 & 1966 & 283.4 & 0.78 \\
\hline 8.0 & 1950 & 487.3 & 0.13 & 28.0 & 1965 & 364.2 & 0.47 & 48.0 & 1989 & 280.3 & 0.80 \\
\hline 9.0 & 1972 & 476.3 & 0.15 & 29.0 & 1967 & 351.5 & 0.48 & 49.0 & 1947 & 268.7 & 0.82 \\
\hline 10.0 & 1974 & 474.6 & 0.17 & 30.0 & 1959 & 350.2 & 0.50 & 50.0 & 1984 & 267.2 & 0.83 \\
\hline 11.0 & 1992 & 471.4 & 0.18 & 31.0 & 1997 & 349.6 & 0.52 & 51.0 & 1977 & 266.5 & 0.85 \\
\hline 12.0 & 1976 & 471.1 & 0.20 & 32.0 & 2005 & 346.6 & 0.53 & 52.0 & 1987 & 254.6 & 0.87 \\
\hline 13.0 & 1985 & 465.2 & 0.22 & 33.0 & 2001 & 343.2 & 0.55 & 53.0 & 1960 & 250.1 & 0.88 \\
\hline 14.0 & 1952 & 461.3 & 0.23 & 34.0 & 2002 & 339.9 & 0.57 & 54.0 & 1973 & 246.5 & 0.90 \\
\hline 15.0 & 1957 & 444.6 & 0.25 & 35.0 & 1970 & 336.2 & 0.58 & 55.0 & 1979 & 246.2 & 0.92 \\
\hline 16.0 & 1953 & 442.1 & 0.27 & 36.0 & 1991 & 335.3 & 0.60 & 56.0 & 1971 & 241.5 & 0.93 \\
\hline 17.0 & 1994 & 441.1 & 0.28 & 37.0 & 1948 & 330.3 & 0.62 & 57.0 & 1958 & 221.3 & 0.95 \\
\hline 18.0 & 1981 & 431.9 & 0.30 & 38.0 & 1978 & 329.4 & 0.63 & 58.0 & 2000 & 176.7 & 0.97 \\
\hline 19.0 & 1996 & 422.0 & 0.32 & 39.0 & 1983 & 329.2 & 0.65 & 59.0 & 1999 & 128.1 & 0.98 \\
\hline 20.0 & 1995 & 410.6 & 0.33 & 40.0 & 1955 & 321.7 & 0.67 & & & & \\
\hline
\end{tabular}




\subsubsection{Maximum rainfall depth, analysis by SCS-CN method}

Estimation max annual rainfall depth for different return period by Gumbel Distribution is listed in Table 3.

Table 3: $\quad$ Maximum annual rainfall depth with different return period.

\begin{tabular}{|l|l|l|l|l|l|}
\hline Return period (year) & 5 & 10 & 50 & 100 & 1000 \\
\hline Frequency coefficient & 1.5 & 2.2504 & 3.902 & 4.6 & 6.907 \\
\hline Reduced Variant & 0.807 & 1.4457 & 2.852 & 3.446 & 5.41 \\
\hline Max Rainfall $(\mathrm{mm})$ & 472.1 & 547.15 & 712.4 & 782.3 & 1013 \\
\hline
\end{tabular}

The runoff depth was calculated for years (1947-2005) of Mosul metrological station using the conceptual model SCS-CN of program WMS7.1 as shown in Figure 5. Monthly rainfall data, area of sub basin, slope of catchment is the input and the output is the runoff. The basin area is in hydrological soil group $\mathrm{C}$ and D with two kind of moisture content i.e. AMC II and AMC III, as the data considered is in the monsoon season. The range of curve number is taken between 75 and 85 for watershed area applying the equation (6).

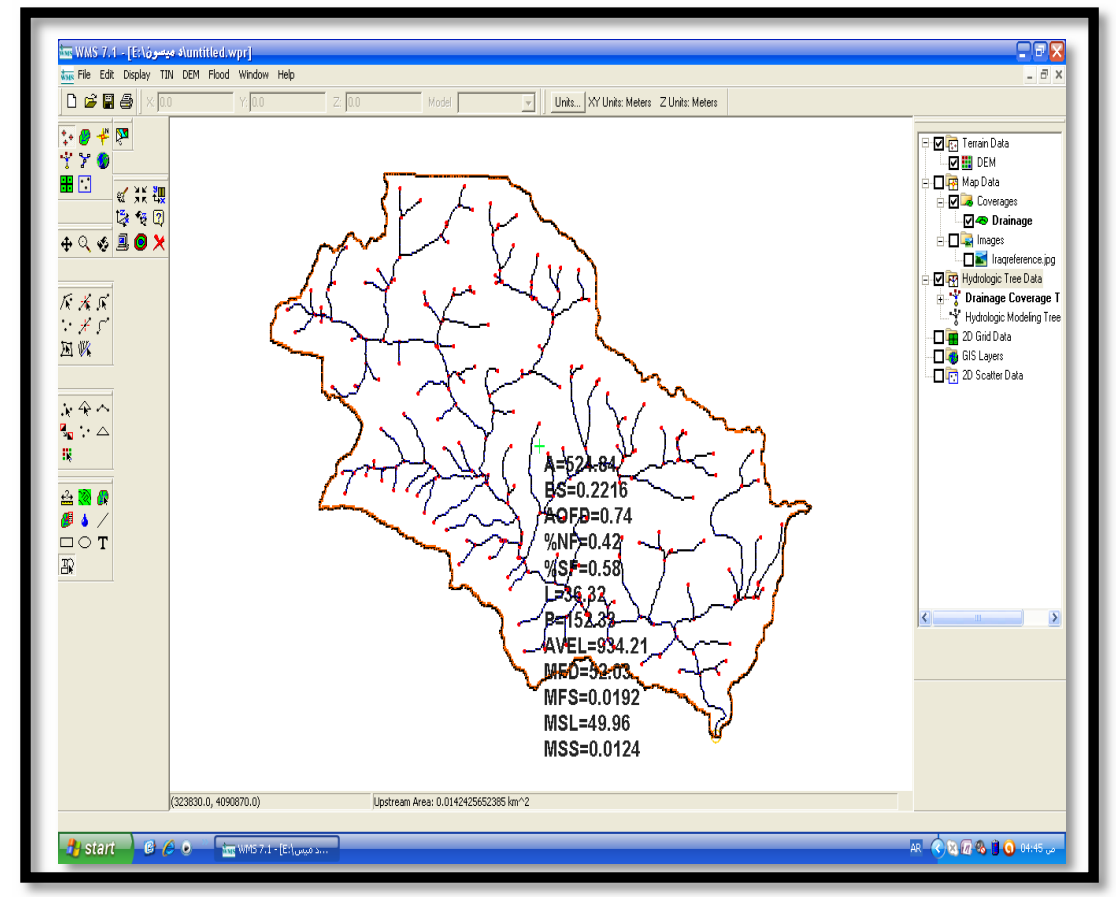

Figure 5: $\quad$ Windows of program WMS 7.1. 


\section{Conclusions}

The following conclusion can be drawn from the study:

- The results of WMS 7.1 program showed that the CN curve number for the area is about 80 . The average annual runoff depth is equal $311.14 \mathrm{~mm}$.

- The incorporation of SCS-CN model and GIS facilitates runoff estimation from watershed and can augment the accuracy of computed data.

- Geographical information system arises as an efficient tool for the preparation of most of the input data required by the SCS curve number model

- Improvements to the model can be made by varying the $\mathrm{CN}$-value and initial abstraction depending on the catchment characteristics per season. This will require a long measuring period to calibrate the model properly.

- Runoff estimation is showing good results for a year as a whole. This is possible as the area under the curve is nevertheless same as being observed, but when it comes to daily discharge the model is not showing satisfactory result as there is a large deviation from the daily runoff observed at many points.

\section{References}

[1] Pandey, A. and A. K. Sahu, "Generation of curve number using remote sensing and Geographic Information System”, http://www.GISdevelopment. net, accessed on Sep. 2007.

[2] Nayak, T.R. and R.K. Jaiswal, "Rainfall-runoff modelling using satellite data and GIS for Bebas river in Madhya Pradesh", IE (I) Journal 84, pp. 47$50,2003$.

[3] Zhan, X. and M. L. Huang, "ArcCN-Runoff: An ArcGIS tool for generating curve number and runoff maps", Environmental Modelling \& Software 19, pp. 875-879, 2004.

[4] Gandini, M.L., and E.J. Usunoff, "SCS Curve Number Estimation Using Remote Sensing NDVI in A GIS Environment", Journal of Environmental Hydrology 12, (Paper 16), 2004.

[5] Akhondi, S., "An investigation of curve number model in flood estimation using, Geographical information System (GIS)", MSc thesis. Tarbiat Modares University, Tehran, 2001.

[6] Clapper, P. E., "Antecedent moisture considerations in the SCS Curve Number rainfall-runoff model": unpubl. MSc thesis, Dept. Civil Engineering, Colorado State Univ., Fort Collins, CO, 104 ,1980.

[7] Dunnington, H. V., "Generation, Migration and Dissipation of Oil in Northern Iraq". Arabian Gulf, Geology and Productivity. AAPG Foreign Reprint Series No. 2, 1958.

[8] Buday, T.; Regional Geology of Iraq, Unpubl. Report, SOM Library, 1973.

[9] Ponce, Victor Miguel, "Engineering Hydrology: Principles and Practices", 1989. 